\title{
Correction to: Design and psychometric evaluation of the fathers' fear of childbirth scale: a mixed method study
}

Seyedeh Fatemeh Ghaffari ${ }^{1} \mathbb{B}$, Hamid Sharif $\mathrm{Nia}^{2} \mathbb{B}$, Forouzan Elyasi ${ }^{3} \mathbb{D}$, Zohreh Shahhosseini ${ }^{4 *}$ (D) and Zohre Mohammadpoorsaravimozafar ${ }^{1}$ (i)

\section{Correction to: BMC Pregnancy Childbirth 21, 222} (2021)

\section{https://doi.org/10.1186/s12884-021-03696-7}

Following publication of the original article [1], the authors reported that the correct second author's name is as below:

First name: Hamid

Family: Sharif Nia

The original article [1] has been updated.

\begin{abstract}
Author details
${ }^{1}$ Mazandaran University of Medical Sciences, Sari, Iran. ${ }^{2}$ Amol Faculty of Nursing, Mazandaran University of Medical Sciences, Sari, Iran. ${ }^{3}$ Psychiatry and Behavioral Sciences Research Center, Sexual and Reproductive Health Research Center, Addiction Institute, Mazandaran University of Medical Sciences, Sari, Iran. ${ }^{4}$ Sexual and Reproductive Health Research Center, Mazandaran University of Medical Sciences, Sari, Iran.
\end{abstract}

Published online: 22 April 2021

\section{Reference}

1. Ghaffari SF, Sharifnia SH, Elyasi F, et al. Design and psychometric evaluation

of the fathers' fear of childbirth scale: a mixed method study. BMC

Pregnancy Childbirth. 2021;21:222 https://doi.org/10.1186/s12884-021-03

696-7.

The original article can be found online at https://doi.org/10.1186/s12884021-03696-7.

* Correspondence: zshahhosseini@yahoo.com

${ }^{4}$ Sexual and Reproductive Health Research Center, Mazandaran University of Medical Sciences, Sari, Iran

Full list of author information is available at the end of the article

(c) The Author(s). 2021 Open Access This article is licensed under a Creative Commons Attribution 4.0 International License, which permits use, sharing, adaptation, distribution and reproduction in any medium or format, as long as you give appropriate credit to the original author(s) and the source, provide a link to the Creative Commons licence, and indicate if changes were made. The images or other third party material in this article are included in the article's Creative Commons licence, unless indicated otherwise in a credit line to the material. If material is not included in the article's Creative Commons licence and your intended use is not permitted by statutory regulation or exceeds the permitted use, you will need to obtain permission directly from the copyright holder. To view a copy of this licence, visit http://creativecommons.org/licenses/by/4.0/ The Creative Commons Public Domain Dedication waiver (http://creativecommons.org/publicdomain/zero/1.0/) applies to the data made available in this article, unless otherwise stated in a credit line to the data. 